\title{
Experimental characterization of a new sustainable sand concrete in an aggressive environment
}

\author{
Mohammed Mani \\ Department of Hydraulic and Civil Engineering, Faculty of Technology, University of El-Oued, 39000, Algeria \\ m.mani39@gmail.com
}

\author{
Meriem Fakhreddine Bouali \\ Department of Civil Engineering, Faculty of Sciences \& Technology, University of Mohamad Cherif Messaadia, Souk Ahras, \\ 41000, Algeria \\ m.bouali@univ-soukahras.d₹̧.meriemfakhreddine@gmail.com,bttp:/ /orcid.org/0000-0002-6986-980X
}

\author{
Abdelouahed Kriker \\ Laboratory of Exploitation and Valorisation of natural Ressources in Arid Arears (E.V.R.N.Z.A), University of \\ KasdiMerbab, Ouargla, 30000, Algeria \\ a_kriker@yahoo.fr
}

\author{
Abdelkader Hima \\ Department of Electrical Engineering, Faculty of Technology, University of El-Oued, 39000, Algeria \\ Abdelkader-bima@univ-eloued.ds, bttp://orcid.org/0000-0002-5533-3991
}

\begin{abstract}
The scarcity of building materials and the shortage of coarse aggregates which represent the main component of concrete is a problem of particular urgency in most third world countries, especially in the vast desert of Algeria. In desert conditions where the environment suffers from the rising water phenomenon and soil aggressivity; the evaluation of existing abundant Sand Dune could be a very good economic solution. Several national and international researches show that Sand Dunes could be exploited in concrete after a granular correction. In this paper, a new Sand resource is proposed as an alternative of natural Sand to perform a Sand Concrete. This experimental study shows that the Sand Concrete based on this new resource of sand dunes of the Algerian desert has a good resistance when used in the ambient Saharan aggressive conditions.
\end{abstract}

KEYWORDS. Durability; Economic; Sand concrete; Sand dune; Naturel sand.

\section{OPEN $\bigcirc$ ACCESS}

Citation: Mani, M., Bouali, M. F., Kriker, A., Hima, A., Experimental characterization of a new sustainable sand concrete in an aggressive environment, Frattura ed Integrità Strutturale, 55 (2021) 50-64.

Received: 06.09 .2020

Accepted: 07.10.2020

Published: 01.01.2021

Copyright: (C) 2021 This is an open access article under the terms of the CC-BY 4.0, which permits unrestricted use, distribution, and reproduction in any medium, provided the original author and source are credited. 


\section{INTRODUCTION}

A lgeria has a vast desert that contains large quantities of Sand Dunes. The abundance of Sand Dunes causes various environmental problems, such as disappearance of reefs and valleys buried in those untapped sand. These regions suffer from a serious environmental phenomenon called "Water Rise phenomenon" [1] which destroys thousands of oases of palm trees [2] that's considered the source of food in the region. This phenomenon also destroyed and ruined buildings gradually [3].

The sand used for construction is almost non-existent in those desolate deserts that don't have neither natural stream, valleys, coasts, nor other sand resources that enable building constructions. Developed countries monitor their national income to support and establish infrastructure construction. In Algeria, the need for this substance during 2012 was about 9 millions cubic meters, and some sources indicate that the consumption rate has reached 20millions cubic meters [4], which made it very expensive: the cubic meter may exceed 3000 DZD (25 USD) [5], while it does not exceed 7USD in Egypt, but in the United States, it does not exceed 3.5 USD.

Several scientific experiments were conducted to study the phenomenon of water rise and its impact on buildings in one hand $[6,7]$. Several studies showed the use of Sand Dunes (SD) as a material in concrete $[8,9]$ in condition that it must have a granular correction [10,11].The main objective of this experimental investigation was the exploitation of existing resources such as the sand of the dunes in the Algerian desert. In the other hand, sand of Oued El-Ratm (SR) was studied and it is known that this type of sand was never used previously in construction fields. These two types of sand are used to produce a Sand Concrete by trying to reveal the effect of rising waters under aggressive conditions on the sand concrete produced by the mixtures.

\section{MATERIALS CHARACTERIZATION}

$\mathrm{I}$ $\mathrm{n}$ this experimental investigation, Oued Souf sand dunes that come from oasis situated in the south east of Algeria was used and improved its properties with naturel sand found in Oued El-Ratm region in order to obtain a formula to improve the sand dunes at a lowest cost. Oued El-Ratm desert region is also located in the heart of the Algerian oases close to five big Cities named: Biskra, Djelfa, Ouargla, El-Oued and Ain Touta Cement. The experiments were carried out in the laboratory of Ouargla and El-Oued University (Algeria). The tested are carried out on a number of samples which varies between 06 and 08 .

\section{Sand}

The sand used in this study is the dune's sand in Guemar (El-Oued) (GSD) and the natural sand from Oued El-Ratm (NSR) area, which was mixed in order to improve the sand dune properties, this technique is used by several researchers [12]. In Table 1 are presented the determined characteristics of these types of sand.

\begin{tabular}{ccccc}
\hline Type & $\begin{array}{c}\text { Bulk } \\
\text { Volumetric } \\
\text { Mass }\left(\mathrm{kg} / \mathrm{m}^{3}\right)\end{array}$ & $\begin{array}{c}\text { Absolut } \\
\text { Volumetric } \\
\text { Mass } \\
\left(\mathrm{kg} / \mathrm{m}^{3}\right)\end{array}$ & $\begin{array}{c}\text { Fineness } \\
\text { modulus } \\
(\mathrm{FM}) \\
(\%)\end{array}$ & $\begin{array}{c}\text { Sand } \\
\text { Equivalent } \\
\text { SE } \\
(\%)\end{array}$ \\
$\begin{array}{c}\text { Guemar Sand Dune } \\
\text { (GSD) }\end{array}$ & $1540 \pm 3$ & $2620 \pm 2$ & $1.61 \pm 0.1$ & $95 \pm 1$ \\
$\begin{array}{c}\text { Naturel Sand Oued El-Ratm } \\
\text { (NSR) } \\
60 \% \text { Naturel Sand (NSR) } \\
+\end{array}$ & $1585 \pm 4$ & $2500 \pm 1$ & $2.35 \pm 0.15$ & $80.09 \pm 1.5$ \\
$\begin{array}{c}+ \\
40 \% \text { Sand Dune (GSD) }\end{array}$ & $1609.2 \pm 2$ & $2609.6 \pm 6$ & $2.24 \pm 0.12$ & $87 \pm 0.5$ \\
\hline
\end{tabular}

Table 1: Experimental characteristics of different types of used sand.

According to the results mentioned in Table 1, it appears that the Guemar's Sand Dune (GSD) has the smaller coefficient of smoothness $(1.61 \%)$ which is outside the acceptable margin areas in building A, B and C. While the natural sand of 
Oued El-Ratm (NSR) and the mixed sand 60\% NSR and 40\% GSD, have coefficients of smoothness equal to $2.35 \%$ and $2.24 \%$ respectively lactated in the margin areas in building.

Fig. 1 shows the grain size distribution of natural sand (NSR) dune, Guemar sand dune (GSD) and the mixture sand (40\% GSD $+60 \%$ NSR) used in the experimental program.

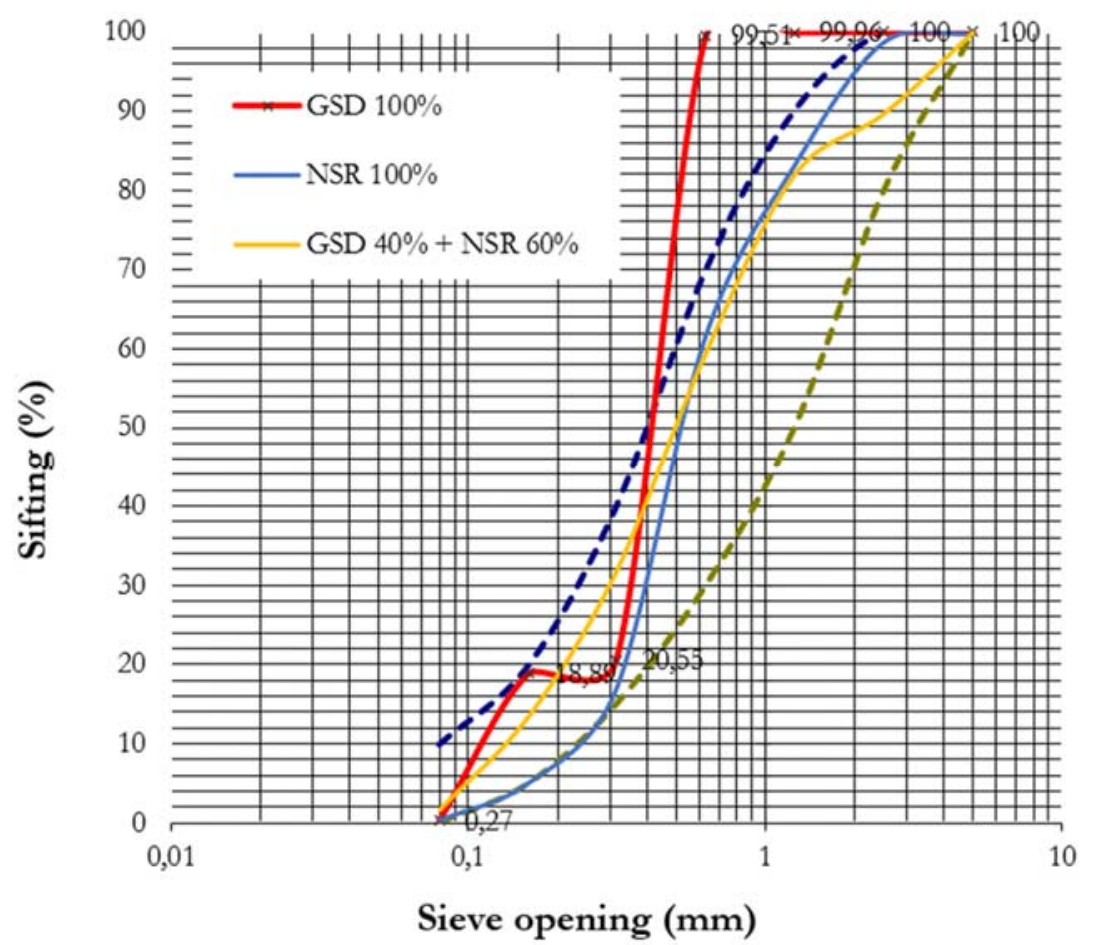

Figure 1: The grain size distribution of sands used in the experimental program.

It is noted from Fig. 1 that the GSD curve is mostly located outside the reference fields and it tends to the smooth side, while the NSR curve is located within the reference curve and is proposed to correct the first curve. The mixture $40 \%$ GSD $+60 \%$ NSR is within the reference areas which make it acceptable.

\section{Cement}

The used cement is I 42.5 (CRS). This cement is specially made to resist sulfate as stipulated in the technical card and as indicated by its name (CRS) i.e. Sulfate Resistant Cement. This type of cement contains a low percentage of tri-calcium aluminate and is characterized by a greater ability to resist sulfate because of the components [13], or because of the process used in the manufacturing. So it is used in cases that requires high resistance to sulfate, and is widely available in the local market. It is produced in Ain-Touta cement factory, which is in compliance with the rules NA 442000 and NA 433: 2002.The values of experimental volumetric mass were computed for the hardened mortars.

\begin{tabular}{ccccc}
\hline Experiences & $\begin{array}{c}\text { Bulk } \\
\text { Volumetric } \\
\text { Mass }\left(\mathrm{kg} / \mathrm{m}^{3}\right)\end{array}$ & $\begin{array}{c}\text { Absolute } \\
\text { Volumetric } \\
\text { Mass } \\
\left(\mathrm{kg} / \mathrm{m}^{3}\right)\end{array}$ & $\begin{array}{c}\text { Primary } \\
\text { stiffness } \\
\text { time }(\mathrm{min})\end{array}$ & $\begin{array}{c}\text { Withdrawal } \\
28 \text { days } \\
(\mu \mathrm{m} / \mathrm{m})\end{array}$ \\
\hline Cement & 2120 & 3034 & 60 & 1000 \\
\hline
\end{tabular}

Table 2: Used cement experimental characteristics [14].

Water

In mixing this concrete tap water is used from the civil engineering laboratory of El-Oued University, which is free of harmful substances such as materials, salts, oils, greases, acids, alkalis, and the soft material as seen in Table 3 . 


\begin{tabular}{lccccccccc}
\hline Salinity & $\mathrm{PH}$ & $\mathrm{HCO}_{3}^{-}$ & $\mathrm{SO}_{4}^{-}$ & $\mathrm{NO}_{3}^{-}$ & $\mathrm{Cl}^{-}$ & $\mathrm{Na}^{++}$ & $\mathrm{K}^{++}$ & $\mathrm{Mg}^{++}$ & $\mathrm{Ca}^{++}$ \\
2799 & 7.75 & 124 & 755 & 14.5 & 755 & 536 & 31 & 125 & 242 \\
\hline
\end{tabular}

Table 3: Chemical characteristics of used the water in the sand concrete mixture.

\section{Environment Conditions}

The studied concrete samples, after removing them from the molds, are kept in water for 28 days, then removed after a while. In order to study the effect of the aggressive medium on the sand concrete, two type of water are considered. The first one is ordinary water (tap water) while the second is aggressive water.

Since the most dangerous elements to concrete are chlorine $(\mathrm{Cl})$ and Sulfur ions $\left(\mathrm{SO}_{4}^{-}\right)$, a medium that contains these two elements is used. The chlorine ions concentration is higher in region (1) (Sidi Mestour region) that contains 1640.23 mg/l, and the higher concentration of Sulfur ions is in the region (2) (Hotel of Louss region) that contains a concentration of Sulfur equal to $3373 \mathrm{mg} / \mathrm{l}$. A most dangerous medium is used considering these two higher concentrations of Chlorine and Sulfur existing respectively in the region (1) and (2). The concentrations are tripled by the authors to speed up the results of its effect on sand concrete.

In this study, those concrete samples were re-positioned in a medium that simulates a rising water layer that's capable of affecting the upstream facility at a later time. Chemical composition of the aggressive water layer characterized by our university's team is illustrated in Table 4 according the regions.

\begin{tabular}{|c|c|c|c|c|c|c|c|c|c|c|c|c|}
\hline $\begin{array}{l}\mathrm{N}^{\circ} \text { of } \\
\text { Point }\end{array}$ & $\begin{array}{l}\mathrm{Ca}^{++} \\
(\mathrm{mg} / \mathrm{l})\end{array}$ & $\begin{array}{l}\mathrm{Mg}^{++} \\
(\mathrm{mg} / \mathrm{l})\end{array}$ & $\begin{array}{l}\mathrm{NH}_{4}^{+} \\
(\mathrm{mg} / \mathrm{l})\end{array}$ & $\begin{array}{c}\mathrm{Cl}^{-} \\
(\mathrm{mg} / \mathrm{l})\end{array}$ & $\begin{array}{l}\mathrm{SO}_{4}^{-} \\
(\mathrm{mg} / \mathrm{l})\end{array}$ & $\begin{array}{l}\mathrm{HCO}_{3}^{-} \\
(\mathrm{mg} / \mathrm{l})\end{array}$ & $\begin{array}{l}\mathrm{NO}_{3}^{-} \\
(\mathrm{mg} / \mathrm{l})\end{array}$ & $\begin{array}{l}\mathrm{NO}_{2}^{-} \\
(\mathrm{mg} / \mathrm{l})\end{array}$ & $\begin{array}{c}\text { COND } \\
\text { (micro } \mathrm{S} / \mathrm{cm})\end{array}$ & $\begin{array}{l}\text { Sal } \\
\% 0\end{array}$ & $\begin{array}{l}\text { TDS } \\
(\mathrm{mg} / \mathrm{l})\end{array}$ & PH \\
\hline Region (1) & 617.23 & 104.51 & 0.15 & 1640.23 & 3363.00 & 51.24 & 64.65 & 0.05 & 7270 & 4.5 & 4390 & 7.43 \\
\hline Region (2) & 637.27 & 75.35 & 0.10 & 588.22 & 3373.00 & 420.00 & 47.81 & 0.01 & 5110 & 3.1 & 3010 & 7.31 \\
\hline
\end{tabular}

Table 4: Chemical composition of the ascending aquatic layer in Oued Souf.

To properly judge the durability of the obtained concrete's body and the good suitability of the sand for possible use in construction, a study of the effect of this medium on the chemical composition of the concrete and on its resistance will be carried out.

\section{PROPORTIONS}

\section{Regular sand concrete (Witness)}

T $\mathrm{n}$ order to obtain a formula for the regular sand concrete that will be used as a witness, a sample of cement and sand was taken as a stipulated according to EN 196-1 rule. The temperature was $(20 \pm 2)^{\circ} \mathrm{C}$ and the relative humidity was greater or equal to $50 \%$. We take an amount of 01 part of cement with 03 parts of sand, while the percentage of water is determined by the experience of operations. After conducting the experiment, we obtain the formulation listed in Table 5. This experiment was performed according to specifications of NFP 18-452 as described in Table 6.

\begin{tabular}{cc}
\hline $\begin{array}{c}\text { Duration in } \\
\text { Seconds }\end{array}$ & Type of Concrete \\
$\mathrm{t} \geq 40$ & Unwieldy dry concrete \\
$20<\mathrm{t} \leq 30$ & Concrete with good workability \\
$10<\mathrm{t} \leq 20$ & Very plastic concrete \\
$\mathrm{t} \leq 10$ & Very fluid concrete \\
\hline
\end{tabular}

Table 5: Type of concrete in function of workability. 
After performing the experiment, we have the following results as illustrated in Table 6 . Then, all the tested concretes are considered flexible according to the standard ENV 206: 1990.

\begin{tabular}{ccc}
\hline Composition & W/C & $\begin{array}{c}\text { Time in } \\
\text { seconds }\end{array}$ \\
\hline $\begin{array}{c}\text { Sand Dune } 100 \%(\mathrm{GSD}) \\
\text { Natural Sand } 100 \%(\mathrm{NSR})\end{array}$ & 0.6 & $30.5 \pm 2$ \\
$40 \%$ Sand Dune (GSD) \\
$\begin{array}{c}+ \\
60 \% \text { Natural Sand (NSR) }\end{array}$ & 0.55 & $23 \pm 2$ \\
\hline
\end{tabular}

Table 6: The obtained results of the workability test.

$V$ arious sand concrete studied

The composition of the samples used in our cubic meter of sand concrete is presented in Table 7 according to different used types of sand.

\begin{tabular}{|c|c|c|c|c|c|}
\hline Composition & $\begin{array}{l}\text { Sand } \\
(\mathrm{Kg})\end{array}$ & $\begin{array}{c}\text { Cement } \\
(\mathrm{Kg})\end{array}$ & $\begin{array}{l}\text { Water } \\
\text { (L) }\end{array}$ & $\mathrm{W} / \mathrm{C}$ & $\begin{array}{c}\text { Time of } \\
\text { streaming- } \\
\text { operational }\end{array}$ \\
\hline Sand Dune $100 \%$ (GSD) & 1396.63 & 465.54 & 279.32 & 0.6 & $2 \pm 30.5 \mathrm{~S}$ \\
\hline Natural Sand 100\% (NSR) & 1390.04 & 463.34 & 254.84 & 0.55 & $2 \pm 25 \mathrm{~S}$ \\
\hline $\begin{array}{c}\text { 40\% Sand Dune (GSD) } \\
+ \\
60 \% \text { Natural Sand (NSR) }\end{array}$ & 1392.39 & 464.13 & 255.27 & 0.55 & $2 \pm 25 \mathrm{~S}$ \\
\hline
\end{tabular}

Table 7: Composition of the sand concrete for the studied samples.

The experimental volumetric mass of the studied concrete are shown in Table 8 relative to each type of used sand.

\begin{tabular}{cccc}
\hline Samples & $\begin{array}{c}\text { Sand Dune } \\
100 \%(\mathrm{GSD})\end{array}$ & $\begin{array}{c}\text { Natural Sand } \\
100 \%(\mathrm{NSR})\end{array}$ & $\begin{array}{c}40 \% \text { Sand Dune (GSD) } \\
+\end{array}$ \\
$\begin{array}{c}\text { Volumetric mass } \\
\left(\mathrm{kg} / \mathrm{m}^{3}\right)\end{array}$ & 2141.5 & 2132.4 & 2135 \\
\hline
\end{tabular}

Table 8: Volumetric mass of studied sand concrete.

Test methods

The experiment is conducted according to EN 196-1 as shown in Fig. 2. The test is carried out using a solid material compression device. This later comes from the sample breaking experiment by bending with a section of $(40 \mathrm{x} 40) \mathrm{mm}$. This sample that's placed between two hard metal plates where the latter is located $1 \mathrm{~cm}$ from the side edges as shown in Fig. 2. The strength is measured by using the following equation (1):

$$
\mathrm{R}_{C}=\frac{F_{C}}{b^{2}}
$$

$\mathrm{R}_{C}$ : Compressive strength (MPa)

$F_{C}:$ Load of rupture $(\mathrm{N})$

$b^{2}$ : Cross-sectional area $(\mathrm{b}=40 \mathrm{~mm})$ 

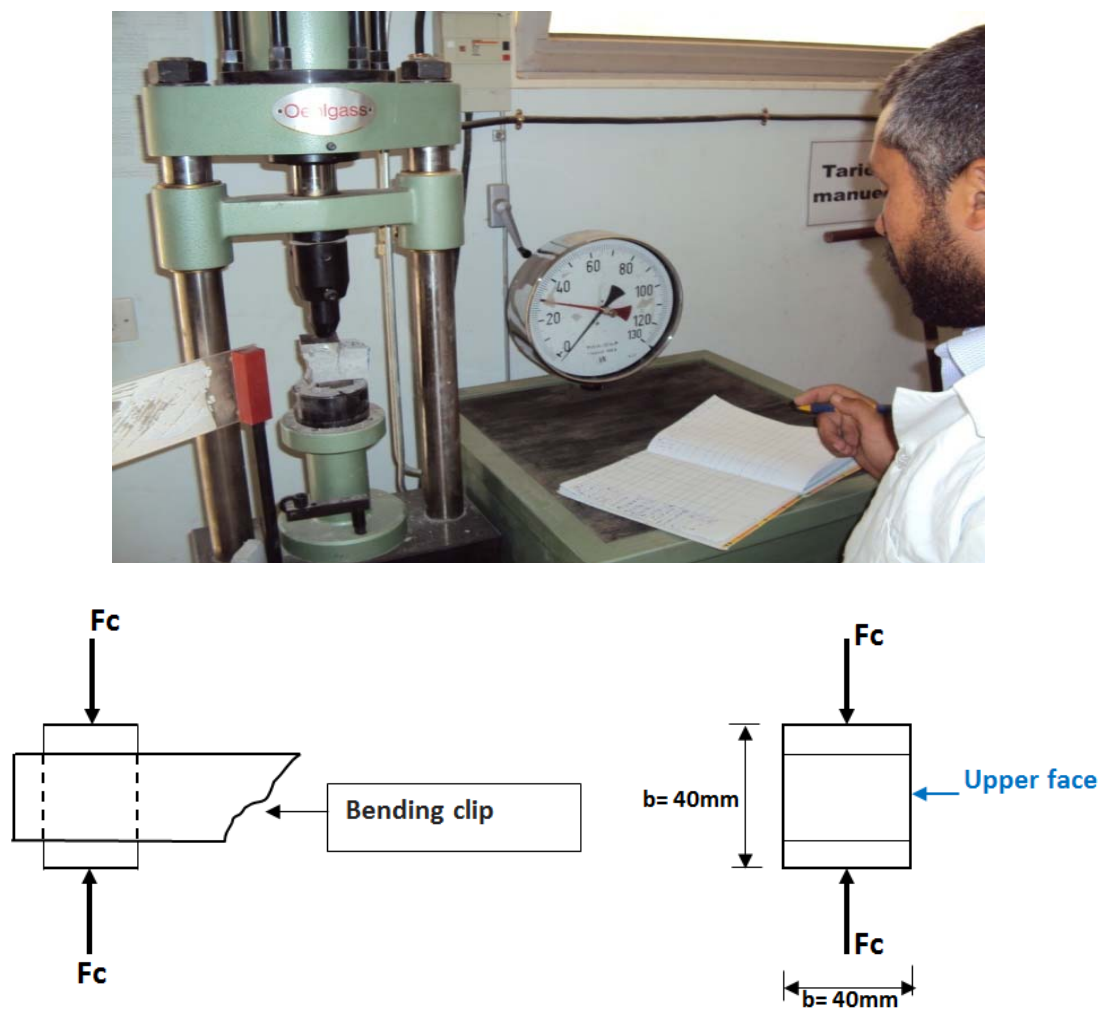

Figure 2: Device in compression test.

\section{RESULTS AND DISCUSSIONS}

\section{Granulometric correction}

$1 \mathrm{O}$ simulate the effect of the rising water phenomenon in aggressive environment, the tested concretes were preserved in two type of water. The first one is a tap water (Fig. 3a) and the second corresponds to aggressive water (Fig. 3b) as indicated above. To distinguish the samples preserved in tap water to those preserved in the aggressive water, the symbol (con) is used to indicate those conserved in the aggressive medium.

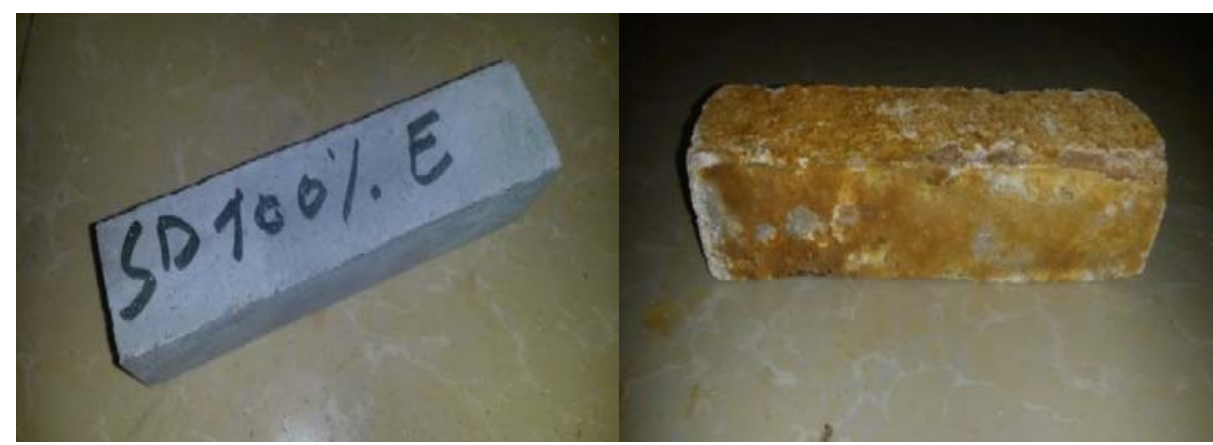

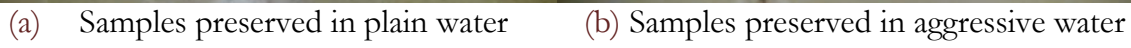

Figure 3: Samples preserved in different medium conditions.

\section{Effect on Compressive Strength}

The compressive strengths are measured for the concretes made with various sands: 100\% Guemar Sand Dune (GSD), $100 \%$ Natural Sand Oued El-Ratm (NSR) and a mixture of 40\% GSD $+60 \%$ NSR. The evolution of compressive 
strength with age for the concrete preserved in plain water and those preserved in the aggressive water are shown in Fig. 4 and Fig. 5 respectively.

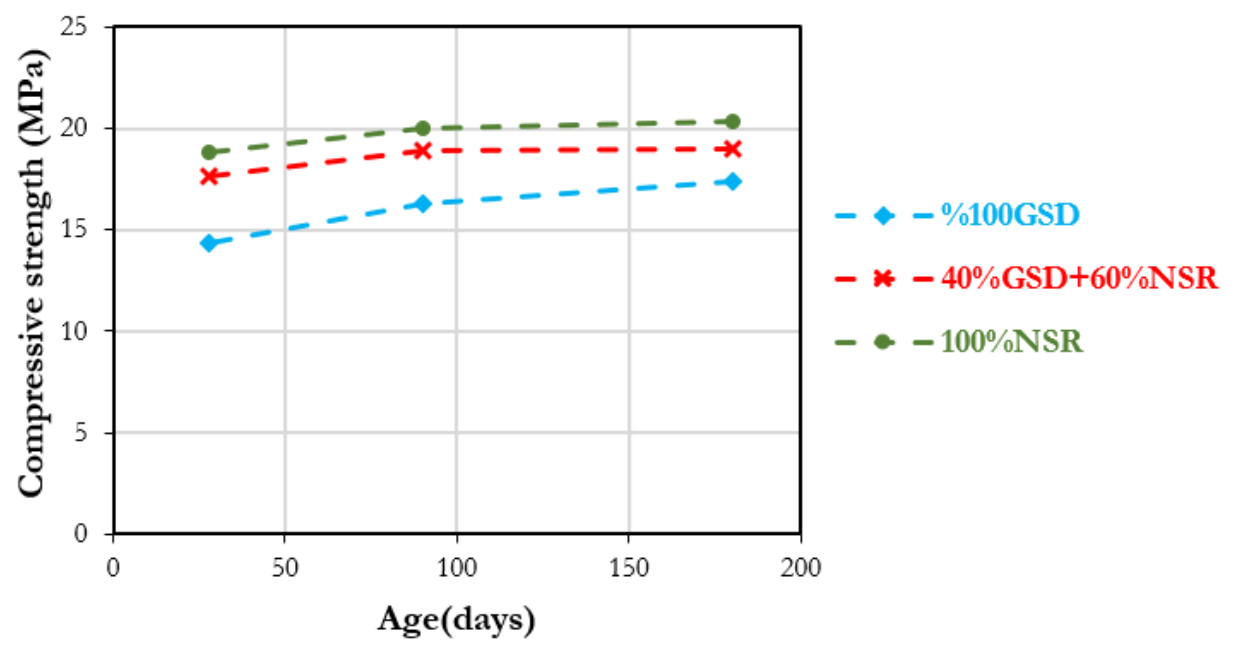

Figure 4: Compressive strength of concretes preserved in plain water in terms of age.

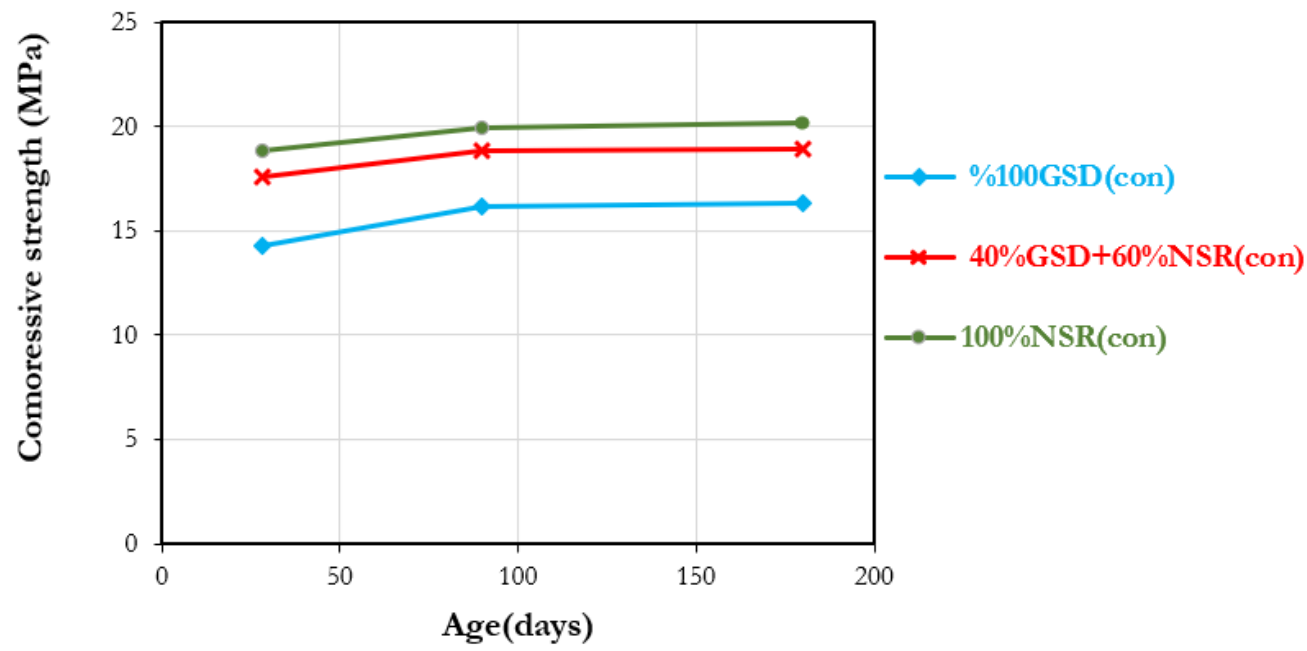

Figure 5: The effect of aggressive water on compressive strength in terms of age.

The Figs. 4-5 showed clearly that the compressive strength of sand concrete mixed between sand dune (GSD) and natural sand (NSR) has improved if compared with sand concrete made by sand dune about $23.13 \%$.

This difference in resistance is due to the difference in granular gradient and the smoothness factor of each type of sand used in these concretes. The smaller coefficient of smoothness indicates that the sand is smooth, which makes the concrete made of it less resistant as described in $[10,15]$.

It is well noted from Figs. 4-5 that the type of medium has a similar effect on the tested concretes. As shown in Fig. 4; the highest compressive strength is recorded for the sand concrete made by the Natural Sand of Oued El-Ratm (NSR), while sand concrete made with Guemar Sand Dunes (GSD) gives the lowest and the mixture gives the intermediate compressive strength. This order of compressive strength magnitude is always valid in the case of concretes stored under aggressive conservations conditions (Fig. 5).

\section{Effect on Flexural Strength}

The flexural strengths are measured for the concretes made with various sands: 100\% Guemar Sand Dune (GSD), 100\% Natural Sand Oued El-Ratm (NSR) and a mixture of 40\% GSD+ $60 \%$ NSR. The evolution of flexural strength with age for the concrete preserved in plain water and those preserved in aggressive water are shown in Fig 6 and Fig. 7 respectively. 


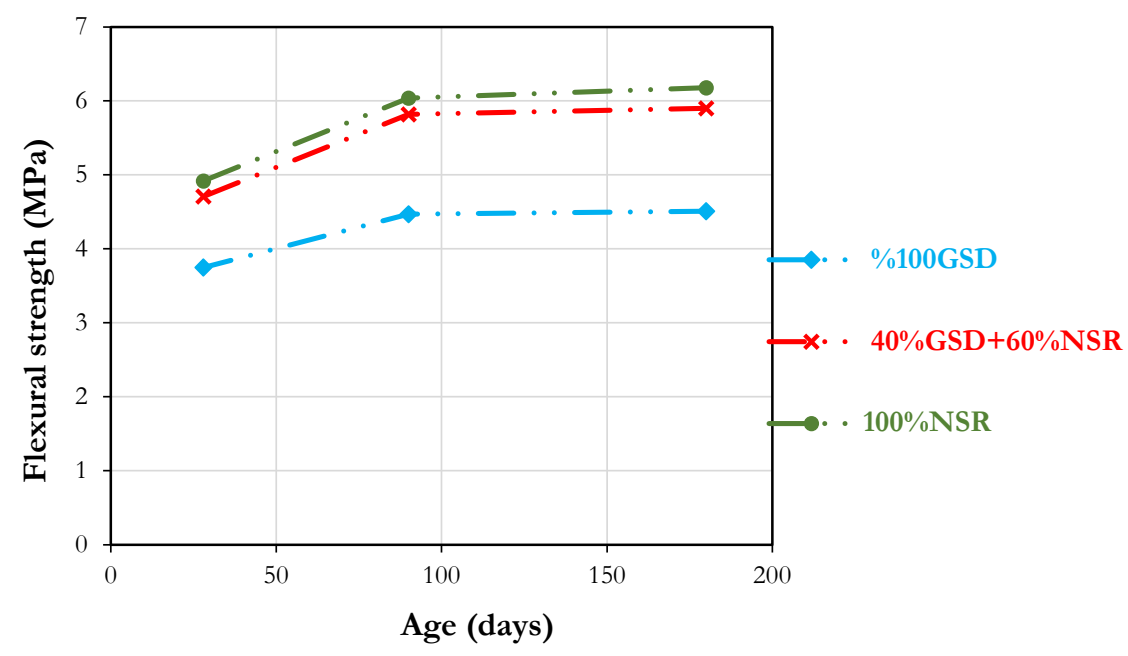

Figure 6: Flexural strength of concretes preserved in plain water in terms of age.

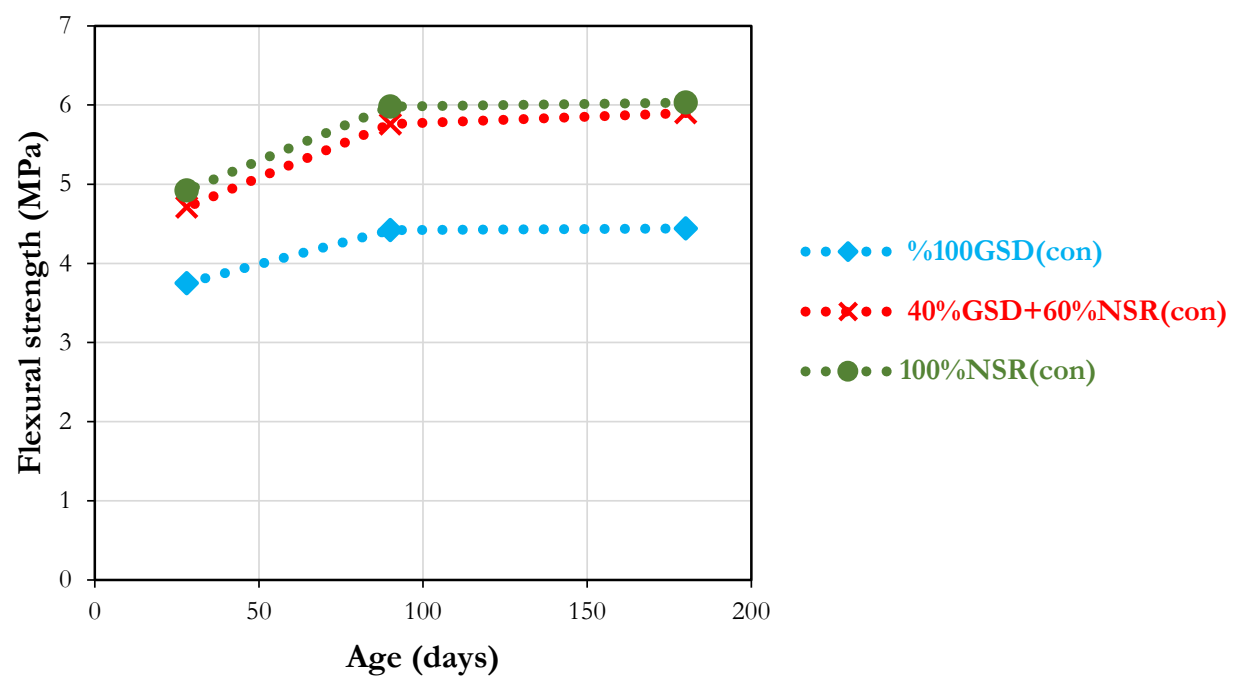

Figure 7: The effect of aggressive water on flexural strength in terms of age.

Similarly to the case of compression, it is noted that the concrete made of $100 \%$ natural sand of Oued El-Ratm (NSR) gave the best resistance to bending. The flexural strength obtained by the sand concrete made by $40 \% \mathrm{GSD}+60 \% \mathrm{NSR}$ is better than the giving by 100\% Guemar Sand Dune (GSD). The resistance of bending increases about $30.20 \%$ if compared with those obtained by $100 \%$ Guemar Sand Dune (GSD) which is the lowest resistance.

This improvement in resistance is due to the combination of the two types of sand [16], which led to improvement in the coefficient of smoothness, as this mixture contained sand particles of larger dimensions than that of the dune sand, which led to a good granular distribution resulting in the closure of the voids [17] that are in the concrete sand dune and thus increase in bending resistance [18].

\section{Effect on the environmental conditions}

The aim of this part is to study the effect of the preservation medium on each type of sand concrete separately. According to Fig. 8, it appears clearly that the effect of the preservation medium on concrete was very weak. This effect on sand dunes concrete (GSD) was $6.67 \%$ did not exceed $0.69 \%$ for Oued El-Ratm concrete (NSR) and achieved just $0.688 \%$ for the mixed sand concrete. This is noticeable in all mechanical resistance, especially compression and flexion. 


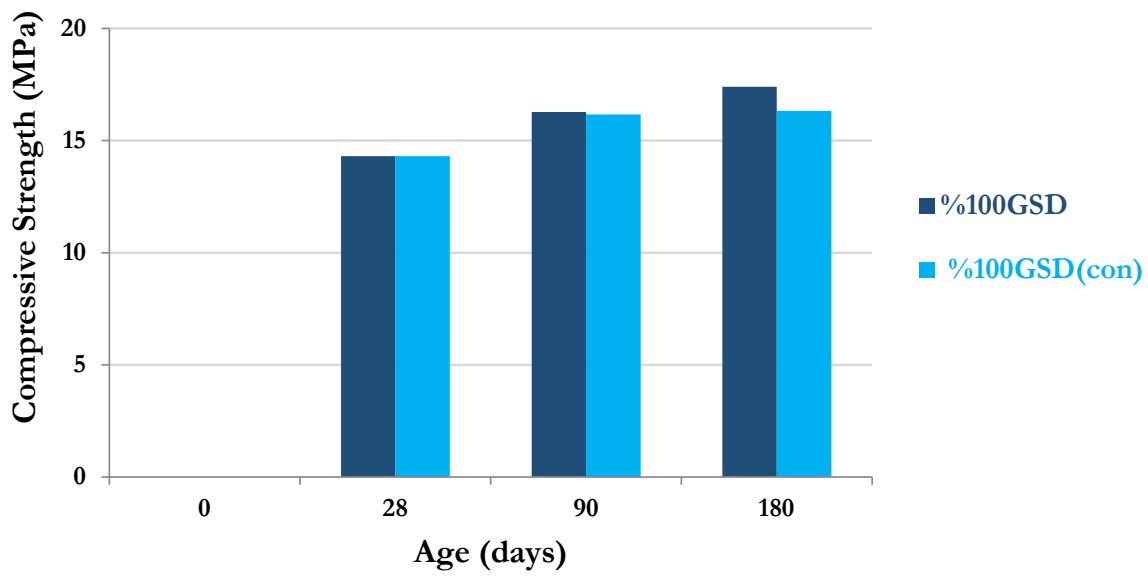

(a) Guemar Sand dune concrete (GSD)

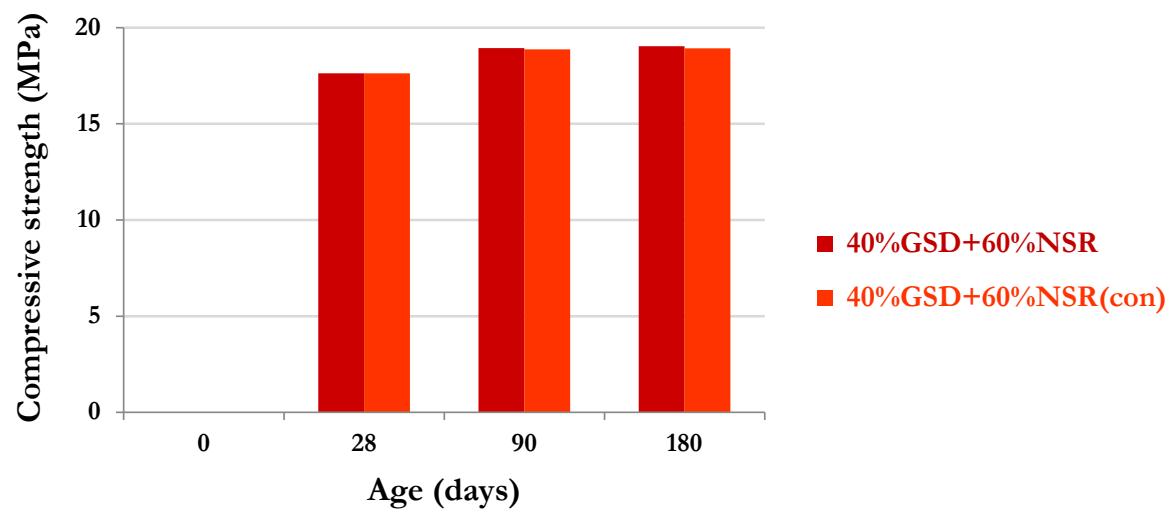

(b) Mixed sand concrete (GSD+NSR)

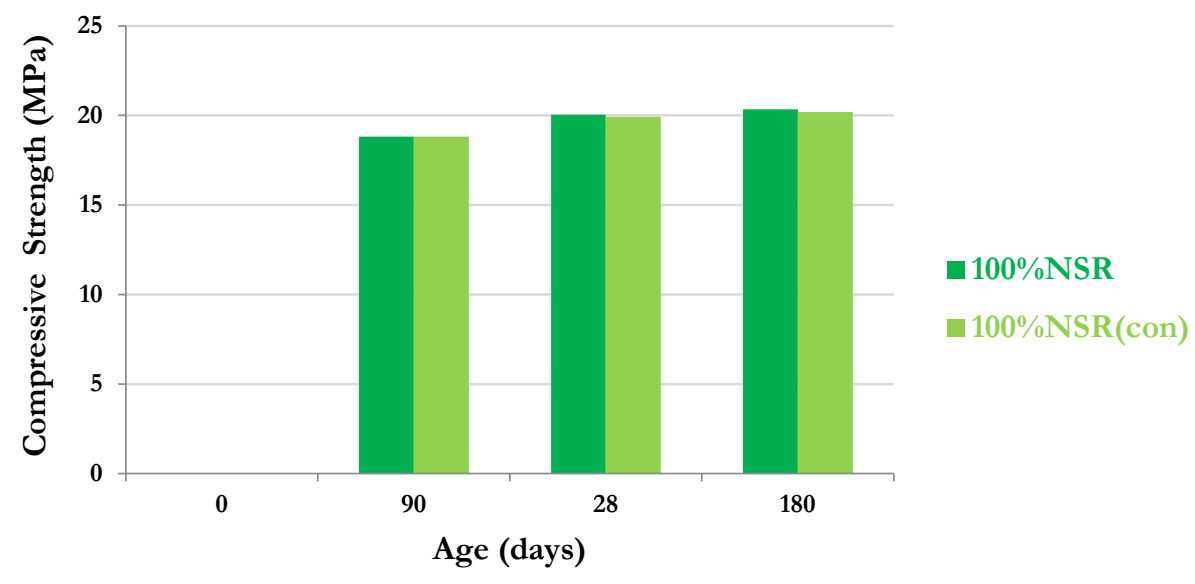

(c) Natural Sand Oued El-Ratm sand concrete (NSR)

Figure 8: Impact of preservation medium in the case of compressive strength. 


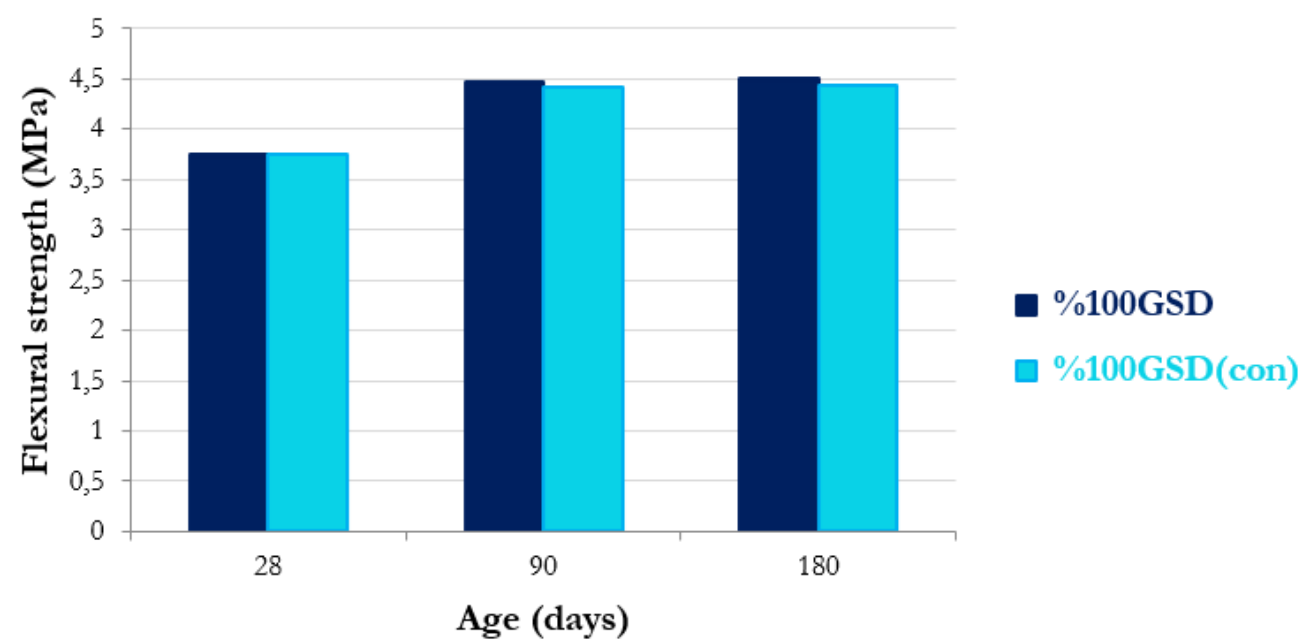

(a) Guemar sand dune concrete (GSD)

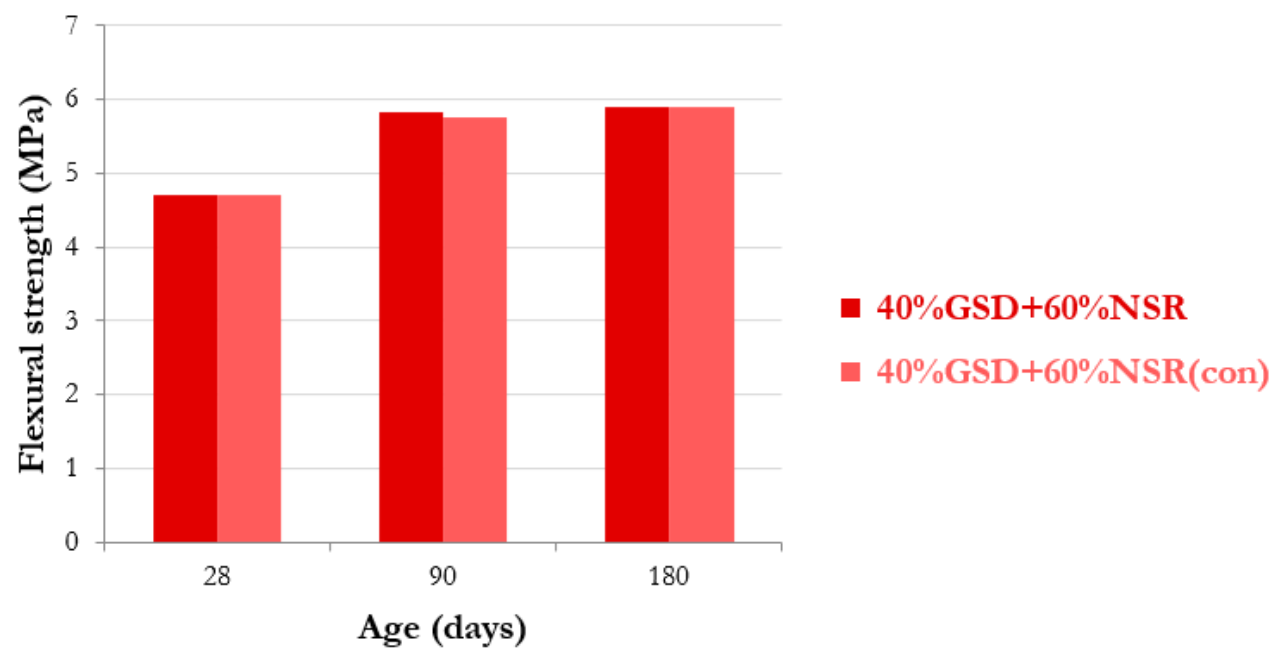

(b) Mixed sand concrete (GSD+NSR)

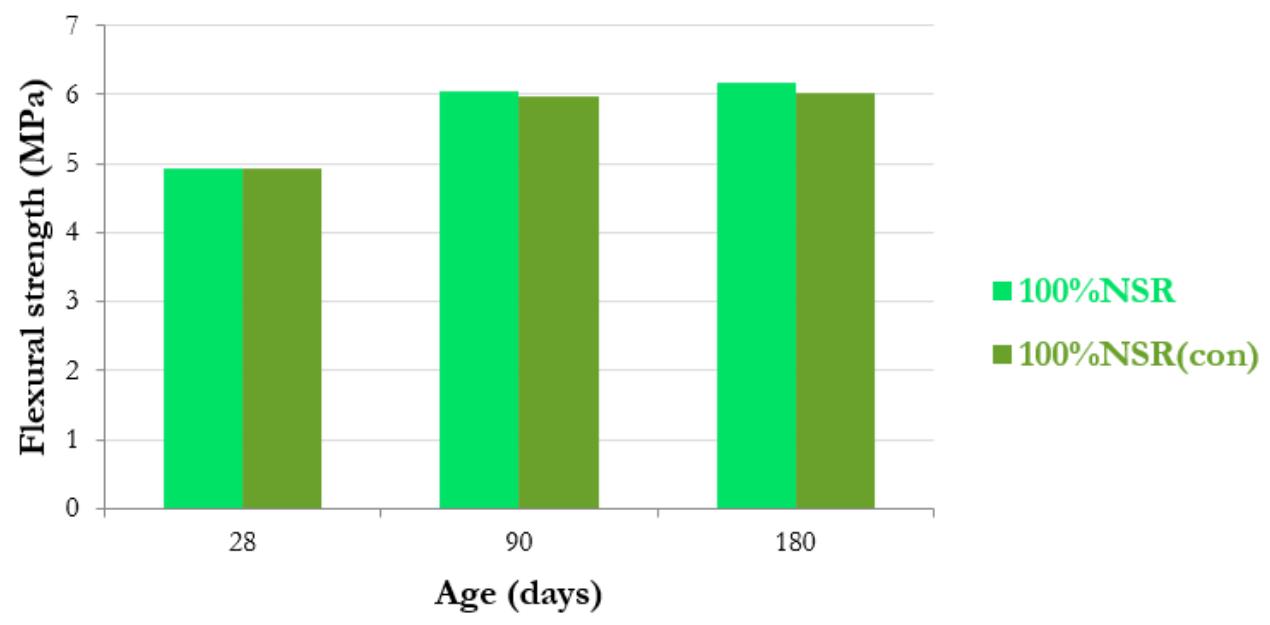

(c) Natural sand dune Oued El-Ratm concrete (NSR)

Figure 9: Impact of preservation medium in the case of flexural strenght. 


\section{Effect on sand grains}

Here, we cannot be sure unless we know how this medium affects each type of sand, so we saved sand samples in this medium in parallel with concrete samples and treated them with dental x-rays (DRX) and revealed with an electronic detector MB. The obtained results for the GSD and NSR sand concrete are shown in Figs. 10 and 11 respectively as follows:

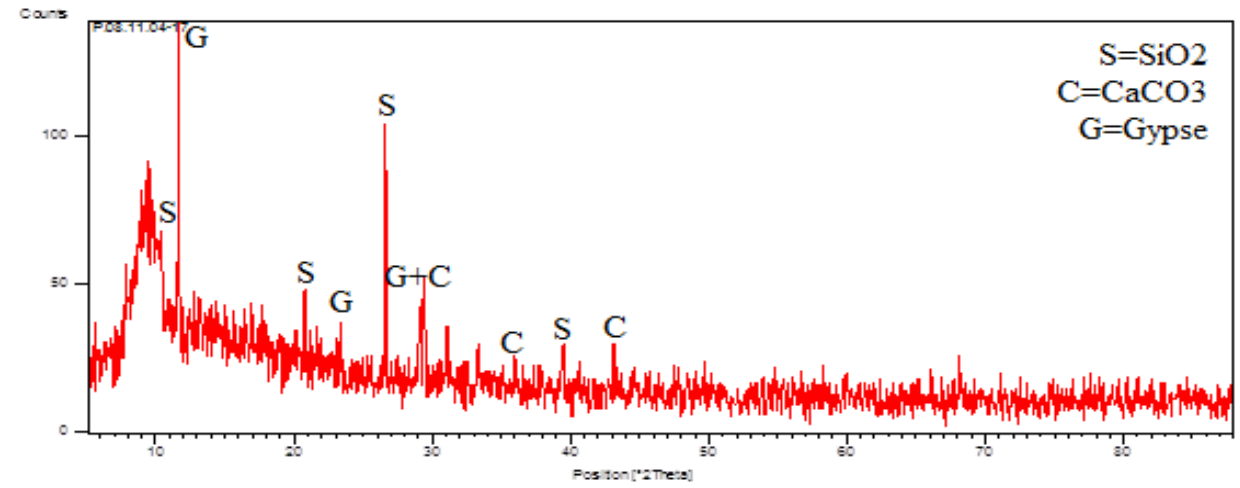

Figure 10: X-ray processing curve for Guemar Sand Dune (GSD) grains.

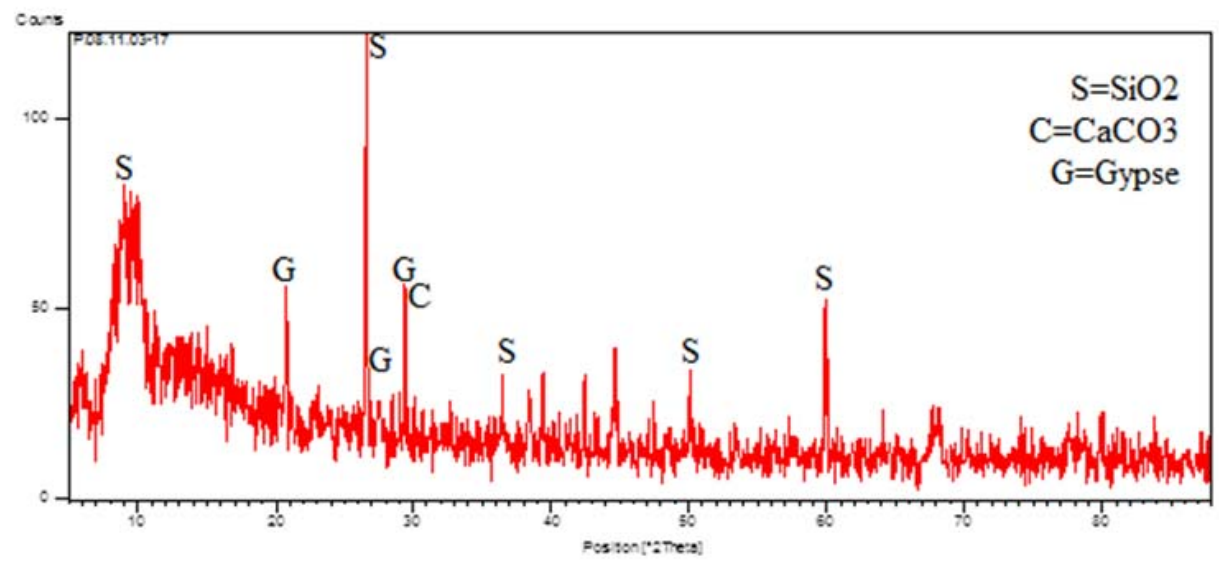

Figure 11: X-ray processing curve for Natural Sand Oued El-Ratm (NSR) grains.

The X-ray treatment DRX for sand dunes and natural sand for Oued El-Ratm (Figs. 10 and 11) shows that its nature is mainly from $\mathrm{SiO}_{2}$ silicates as quatrz is the main metal of its compostion, and on a secondary basis there are some elements such as $\mathrm{CaCO}_{3}$ and gypsum with traces of clay minerals in the other one.

According to [19], the absence of traces of active carbon rocks or stones such as dolomite or magnesite in fine debris means that the sands studied have a chemically stable composition, and are capable of producing slurry or concrete without alkali-alkaline reaction.

Nor did the effects of harmful substances that make up the preservation medium appear on these sand compositions, which indicate their non-interaction with them and thus the stability of this substance in this medium and with studied concentration.

\section{The effect on the bond resulting from the rehydration of cement}

After removing the samples from the preservation medium, it was noticed that a thin white layer formed on the surface of the samples, which it was processed with X-ray. The results of this treatment are shown in Figs. 12, 13 and 14 for 100\% GSD samples, $40 \%$ GSD + 60\% NSR and 100\% NSR samples respectively. 


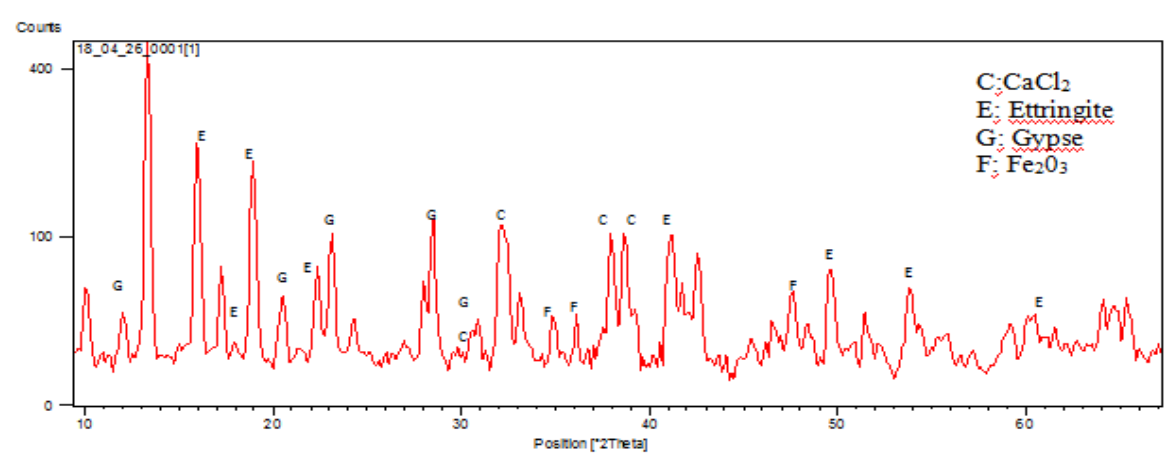

Figure 12: X-ray treatment curve for sediments on 100\% GSD samples.

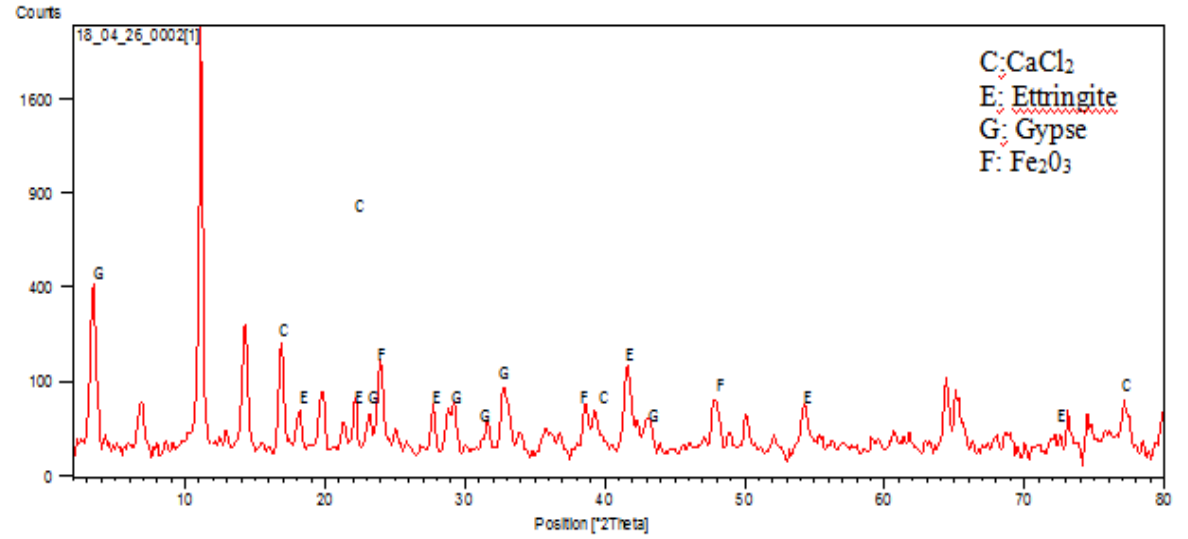

Figure 13: X-ray treatment curve for sediments on samples $40 \%$ GSD $+60 \%$ NSR.

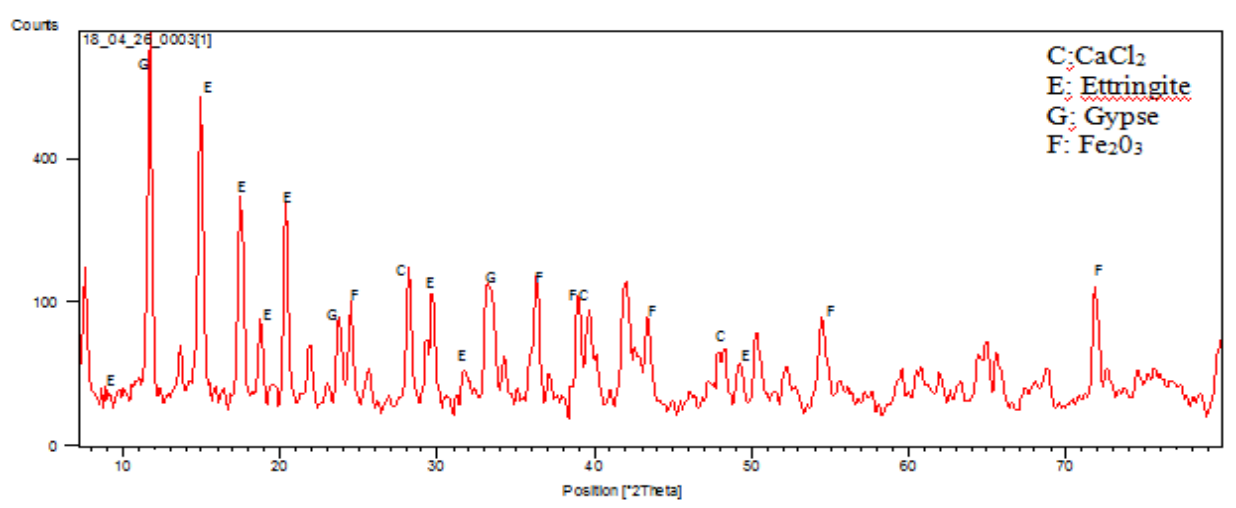

Figure 14: X-ray treatment curve for sediments on 100\% NSR samples.

The results of X-ray treatment shown in Figs. 12, 13 and 14 allows us to say that these white deposits are made of Trangite known by its chemical formula $3 \mathrm{CaO} . \mathrm{Al}_{2} \mathrm{O}_{3} \cdot 3 \mathrm{CaSO}_{4} \cdot 31 \mathrm{H}_{2} \mathrm{O}$ as it showed a new compound containing elements from the aggressive medium, which is $\mathrm{CaCl}_{2}$, as well as the gypsum substance known as $\mathrm{CaSO}_{4} .2 \mathrm{H}_{2} \mathrm{O}$.

As a result of the interaction of $\mathrm{C}-\mathrm{S}-\mathrm{H}$ and $\mathrm{CaC}$, the basic components of cementation hydration with the harmful ions $\mathrm{Cl}$ and $\mathrm{SO}^{4}$ gives a new white substance deposited on the surface of the samples according to the following reaction equation:

$$
\text { Gypsum } \mathrm{H}_{2} \mathrm{SO}_{4}+\mathrm{Ca}(\mathrm{OH})_{2}---------------------\mathrm{CaSO}_{4} \cdot 2 \mathrm{H}_{2} \mathrm{O}
$$

This has been transformed into Trangit in the presence of Tri calcium Yemenite C3A according to the formula: 


$$
3 \mathrm{CaSO}_{4}+3 \mathrm{CaO} . \mathrm{Al}_{2} \mathrm{O}_{3} \cdot 6 \mathrm{H}_{2} \mathrm{O}+25 \mathrm{H}_{2} \mathrm{O}-----------3 \mathrm{CaO} . \mathrm{Al}_{2} \mathrm{O}_{3} \cdot 3 \mathrm{CaSO}_{4} \cdot 31 \mathrm{H}_{2} \mathrm{O}
$$

The presence of gypsum may be through the interaction of sulfate acid with the calcium element in the sand used in mixing the concrete.

As for calcium chlorides, they were produced through the reaction:

$$
\text { Calcium chloride } \mathrm{HCl}+\mathrm{Ca}(\mathrm{OH})_{2}------------\mathrm{H}_{2} \mathrm{O}+\mathrm{Ca}(\mathrm{Cl})_{2}
$$

These precipitates, which formed a white layer, have weak pressure resistance compared to concrete resistance. This layer was superficial and thin, but it affected the resistance with a weak degree as well [20-23].

This layer is natural to form because a type of cement that is resistant to the sulfate material [24] was used. The behavior of the products of this cement's interaction with water is known to be a white layer consisting of these compounds $\left(\mathrm{CaSO}_{4} .2 \mathrm{H}_{2} \mathrm{O}\right.$ and $\left.\mathrm{CaCl}_{2}\right)$ and others to play the role of guard for the concrete core from entering and penetrating harmful materials from the aggressive medium surrounding the concrete body $[20,25,26]$.

\section{CONCLUSION}

$\mathrm{S}$ and concrete has a large interest in many countries for the resources available. Several national and international researches show that Sand Dunes could be exploited in concrete after a granular correction. Sand of Oued El-Ratm (SR) was never used previously in construction fields in Algeria. The phenomenon of rising aggressive water existing in the desert of Algeria is simulated in this experimental investigation by conserving the sand concretes samples in aggressive water with high concentration of chlorine $(\mathrm{Cl}-)$ and Sulfur ions $\left(\mathrm{SO}_{4}^{-}\right)$which simulates the water existing in the desert area of Algeria.Three types of concrete made with various sands: 100\% Guemar Sand Dune (GSD), 100\% Natural Sand Oued El-Ratm (NSR) and a mixture of 40\% GSD+ 60\% NSR are considered in this study.

The evolution of compressive and flexural strength with age for the concrete preserved in plain water and those preserved in the aggressive water are measured experimentally and the effect of the aggressive water is studied for all types of sand concretes considered in this work. The main objective of this experimental investigation was the exploitation of existing resources such as the sand of the dunes in the Algerian desert.

The key findings of this experimental investigation are:

- Natural Oued El-Ratm sand (NSR) has an acceptable coefficient of smoothness equal to 2.35, and its graininess is within the reference range.

- Guemar Sand Dune (GSD), its fineness coefficient is acceptable equal to 1.61, which is small if the sand is fine, and its grainy gradation is mostly outside the reference range, so we corrected it by mixing it with Natural Oued El-Ratm sand (NSR).

- The mixing ratios that gave an acceptable value for smoothness factor are $60 \%$ (NSR) $+40 \%$ (GSD), which gave a coefficient of smoothness equal, to 2.24 , and we curved it within the reference curve.

- The resistance of sand concrete made with $100 \%$ (NSR) of Natural Oued El-Ratm sand is good compared to the resistance of regular mortar. This opens new horizons to take advantage of this abundant mine, which will yield significant returns for investing countries and companies.

- Compression resistance improved when $60 \%$ of Natural Oued El-Ratm sand (NSR) was added to Guemar Sand Dune (GSD), an acceptable improvement of $23.13 \%$ compared to witness concrete (dune sand concrete).

- The bending resistance improved when adding 60\% 60\% of Natural Oued El-Ratm sand (NSR) was added to Guemar Sand Dune (GSD) was an acceptable improvement of 30.20\% compared to witness concrete (dune sand concrete).

Using the sands of Oued El-Ratm sand (NSR) alone or mixed with sand dunes gives concrete resistance to the aggressive media present in the oases of Oued Souf if we use cement anti-sulfate CRS. This means that the used sand was not affected by the aggressive environment, which enables us to exploit it in construction.

This means valuing the sand of the dunes in the Algerian desert, using them in construction, to provide us with two important things:

1. Preserving the environment from the movement of this sand by utilizing it and thus reducing its quantities.

2. Contributing to providing new building sand to cover the shortage of natural sand suitable for construction. 
Such a study, which deals with discovering new mines and resources for building materials, would open fields of competition for various international companies to invest in the exploitation of such new resources and thus benefit the countries that own them.

\section{NOMENClature}

SD: Sand Dunes

SR: Sand of Oued El-Ratm

GSD: Guemar Sand Dune (El-Oued)

NSR: Natural sand from Oued El-Ratm

FM: Fitness modulus

SE: Sand equivalent

CRS: Sulfate Resistant Cement

W/C: Water/Cement ratio

Rc: Compressive strength $(\mathrm{MPa})$

Fc: Load of rupture $(\mathrm{N})$

$\mathrm{b}^{2}$ : Cross-sectional area

DRX: Dental x-rays

MB: Electronic detector

\section{REFERENCES}

[1] Boualem, B. and Salah, B. M. (2018). Gestion du phénomène de la remontée des eaux dans la région d'El Oued (SE Algérie) et la possibilité d'utilisée les eaux usées épurées en irrigation. International Journal of Environment and Water (ISSN 2052-3408), 7(2), pp. 82-91.

[2] Miloudi, A. M. and Remini, B. (2018). The ghout of Souf: An original hydroagricultural system. GeoScience Engineering (ISSN 1802-5420), LXIV (3), pp. 30-37.

[3] Abimouloud, Y. and Kriker, A. (2016, July). Effect of exposure delay of concrete into aggressive environment. In AIP Conference Proceedings 1758(1), p. 030008. AIP Publishing LLC.

[4] Riad, KH. (2013). 20 milliards de dinars les pertes du trésor public par an en raison du vol de sable, Newspaper Elbiled.

[5] Mhamed, M. (2015). Les projets de logement sont menaces d'arret en raison des prix élevés des matériaux de construction, Newspaper EL Khabar.

[6] Djedid, T., Guettala, A. and Mani, M. (2019). Study of the workability and mechanical strength of concrete in the face of upwelling (Case of the El Oued Region of Algeria). Journal of Fundamental Applied Science. 11(1), pp. 368-384.

[7] Logbi, A., Kriker, A. and Snisna, Z. (2017, February). Effects of mineral additions on durability and physicomechanical properties of mortar. In AIP Conference Proceedings 1814(1), p. 020032. AIP Publishing LLC.

[8] Belferrag, A. (2016). Contribution à l'amélioration des propriétés mécaniques et rhéologiques des bétons de sable de dunes (Doctoral dissertation, Université Mohamed Khider-Biskra).

[9] Tafraoui, A. (2009). Contribution à la valorisation du sable de dune de l'erg occidental (Algérie) (Doctoral dissertation, Toulouse, INSA).

[10] Belferrag, A., Kriker, A., Abboudi, S. and Bi, S. T. (2016). Effect of granulometric correction of dune sand and pneumatic waste metal fibers on shrinkage of concrete in arid climates. Journal of Cleaner Production, 112, pp. 30483056.

[11] Mohammed, M., Abdelouahed, K. and Allaoua, B. (2017, February). Compressive strength of dune sand reinforced concrete. In AIP Conference Proceedings 1814(1), p. 020023. AIP Publishing LLC.

[12] Bilal, H., Yaqub, M., Rehman, S. K. U., Abid, M., Alyousef, R., Alabduljabbar, H. and Aslam, F. (2019). Performance of Foundry Sand Concrete under Ambient and Elevated Temperatures. Materials, 12(16), 2645.

[13] Centre D'information Sur Le Cimente Et Ses Application (2009). Guide de prescription des ciments pour des constructions durables".

[14] Fiche technique de cimenterie Ain-touta. (2018).Algeria. 
[15] Claude, B., Gérard, B. and Pierre-Claude, A. (1984). Role des caractéristiques physico-mecaniques des granulats sur la resistance en compression de betons a trés haute resistance. Bulletin of the International Association of Engineering Geology-Bulletin de l'Association Internationale de Géologie de l'Ingénieur, 30(1), pp. 187-191.

[16] Awoyera, P., Wisdom, A., Chukwudi, O., Ekedum, K., Adediran, A. and Mebitaghan, C. (2018). Curing, thermal resistance and bending behaviour of laterised concrete containing ceramic wastes. Cogent Engineering, 5(1), 1485476.

[17] Mavroulidou, M. and Lawrence, D. (2019). Can waste foundry sand fully replace structural concrete sand? Journal of Material Cycles and Waste Management, 21(3), 594-605.

[18] Zhang, M., Liu, H., Sun, S., Chen, X. and Doh, S. I. (2019). Dynamic Mechanical Behaviors of Desert Sand Concrete (DSC) after Different Temperatures. Applied Sciences, 9(19), 4151.

[19] Seif, A. and Sedek, E. S. (2013). Performance of cement mortar made with fine aggregates of dune sand, Kharga Oasis, Western desert, Egypt: An experimental study. Jordan Journal of Civil Engineering, 159(3164), pp. 1-15.

[20] Laoufi, L., Senhadji, Y., Benazzouk, A., Langlet, T., Mouli, M., Laoufi, I. and Benosman, A. S. (2016). Evaluation de la durabilité de mortiers pouzzolaniques exposés à une attaque chimique (Assessment of pozzolanic mortars sustainability exposed to chemical attack). J. Mater. Environ. Sci, 7(5), pp. 1835-1845.

[21] Huang, Q., Wang, C., Zeng, Q., Yang, C., Luo, C. and Yang, K. (2016). Deterioration of mortars exposed to sulfate attack under electrical field. Construction and Building Materials, 117, pp. 121-128.

[22] Harbi, R. (2018). Propriétés physico-mécaniques et durabilité des Mortiers avec additions minérales (Doctoral dissertation).

[23] Melais, F. Z. (2016). Durabilité des bétons de sable fibres dans les différents milieux agressifs " effets de la nature des fines d'ajouts et fibres". dunes (Doctoral dissertation, Université Badji Mokhtar Annaba).

[24] Salhi, A., Kriker, A., Tioua, T., Abimiloud, Y. and Barluenga, G. (2016, July). Durability of visitable concrete sewer gallery under the effect of domestic wastewater. In AIP Conference Proceedings 1758(1), p. 030025. AIP Publishing LLC.

[25] Khelifa, M. R. (2009). Effet de l'attaque sulfatique externe sur la durabilité des bétons autoplaçants (Doctoral dissertation).

[26] Nasser, A. (2010). La corrosion des aciers dans le béton à l'état passif et par carbonatation: prise en compte des courants galvaniques et des défauts d'interface acier-béton (Doctoral dissertation, Université de Toulouse, Université Toulouse III-Paul Sabatier). 